\title{
HUBUNGAN PENGETAHUAN IBU DENGANKELENGKAPAN IMUNISASI DASAR DI WILAYAH KERJA PUSKESMAS SINDANG BELITIR ILIR
}

\author{
The Relationship Between Mother's Knowledge With The Completennes Of \\ Basic Immunization Of The Primary Health Care In Sindang Belitiilir
}

\author{
Rafidaini Sazarni Ratiyun ${ }^{1 *}$, Al-Ashar ${ }^{1}$, Buyung Keraman ${ }^{2}$ \\ IProgram Studi Ilmu Keperawatan, Sekolah Tinggi Ilmu Kesehatan Tri Mandiri Sakti, Bengkulu \\ *e-mail: rafidainisazarni@gmail.com
}

\begin{abstract}
ABSTRAK
Program imunisasi adalah bagian dari pelayanan kesehatan dasar. Bayi mendapatkan imunisasi atau tidak pada dasarnya tergantung dari pengetahuan ibu. Penelitian ini bertujuan untuk mempelajari hubungan pengetahuan ibu dengan kelengkapan imunisasidasar di Wilayah Kerja Puskesmas Sindang Belitir Ilir Kabupaten Rejang Lebong. Penelitian ini merupakan penelitian kuantitatif dengan desain survey analitik yang menggunakan rancangan penelitian cross sectional. Sampel dalam penelitian adalah ibu yang memiliki bayi berusia 9-12 bulan.Pengumpulan data dengan menggunakan teknik accidental sampling sebanyak 61 orang. Analisis data menggunakan Uji Chi-Square dengan $\alpha=0,05$. Hasil uji statistik Pearson Chi-Square diperoleh nila $\mathrm{p}=0,001<0,05$ jadi signifikan, sehingga disimpulkan terdapat hubungan yang signifikan antara pengetahuan ibu dengan kelengkapan imunisasi dasar bayi di Wilayah Kerja Puskesmas Sindang Belitir Ilir Rejang Lebong. Diharapkan kepada pihak Puskesmas untuk mengoptimalkan pendekatan dan promosi yang lebih tepat lagi untuk mencapai target program kelengkapan imunisasi dasar.
\end{abstract}

Kata Kunci: Pengetahuan, Imunisasi Dasar

\begin{abstract}
The immunization program is part of basic health services. Babies get immunized or not basically depends on the mother's knowledge. This study aims to study the relationship between maternal knowledge and the completeness of basic immunization in the work area of the Primary Health Care in Sindang Belitir Ilir Rejang Lebong Regency. This research is a quantitative research with analytic survey design that uses cross sectional research design. The sample in this study is mothers who have babies aged 9-12 months. Collecting data using accidental sampling techniques as many as 61 people. Data analysis using Chi-Square Test with $\alpha=0.05$. The Pearson Chi-Square statistical test results showed that $p$ value $=0.001<0.05$ became significant, so it was concluded that there was a significant relationship between maternal knowledge and completeness of basic infant immunization in the working area of Primary Health Care in Sindang Belitir Ilir Rejang Lebong. It is expected that the Puskesmas will optimize approaches and promotions that are more appropriate to achieve the basic immunization completeness program targets.
\end{abstract}

Keywords: Knowledge, Immunization Completeness

\section{PENDAHULUAN}

Pemberian imunisasi merupakan salah satu indicator dalam keberhasilan pencapaian salah satu target dari Tujuan Pembangunan Berkelanjutan (TPB) yaitu mengakhiri kematian bayi baru lahir dan balita yang dapat dicegah. Pemberian imunisasi merupakan bentuk intervensi kesehatan publik yang memiliki kemampuan untuk mengendalikan dan memberantas penyakit infeksi yang mematikan (Badan Pusat Statistik, 2018).

Setiap tahun lebih dari 1,4 juta anak didunia meninggal karena berbagai penyakit yang sebenarnya dapat dicegah dengan imunisasi. Pentingnya pemberian 
imunisasi dapat dilihat dari data WHO yang menunjukkan bahwa tiap tahun setidaknya 1,7 juta anak dapat diselamatkan berkat vaksin yang sudah tersedia dan diberikan gratis di Puskesmas oleh karena itu, untuk mencegah bayi dan balita menderita beberapa penyakit yang berbahaya, imunisasi pada bayi dan balita harus lengkap serta diberikan sesuai jadwal (Marmi \& Rahardjo, 2012).

Cakupan imunisasi dasar lengkap di Indonesia dalam lima tahun terakhir selalu di atas $85 \%$, namun masih belum mencapai target Renstra Kementerian Kesehatan yang ditentukan. Pada tahun2018 imunisasi dasar lengkap di Indonesia sebesar 90,61\%. Angka ini sedikit di bawah target Renstra tahun 2018 sebesar 92,5\%. Sedangkan menurut provinsi, terdapat 13 provinsi yang mencapai target Renstra tahun 2018.Data tahun 2017, Provinsi Jawa Tengah, DKI Jakarta, NusaTenggara Barat, dan Sumatera Selatan telah mendapatkan imunisasi dasar lengkap. Sedangkan provinsidengan capaian terendah yaitu Papua $(29,60 \%)$, Nusa Tenggara Timur(51,72\%) dan Aceh (55,26\%). Provinsi Bengkulu telah mencapai target renstra dengan cakupan imunisasi dasar lengkap pada bayi tahun 2018 sebesar 95,92\% (Kemenkes RI, 2019).

Cakupan imunisasi tertinggidi Provinsi Bengkulu berada di Kabupaten Seluma mencapai (98\%), dan cakupan terendah adalah kabupaten Kepahiang sebesar (89\%) dan Kabupaten Rejang Lebong sebesar (90\%) (Dinas Kesehatan Provinsi Bengkulu, 2019).

Pemerintah wajib memberikan imunisasi lengkap kepada setiap bayi dan anak. Pemberian imunisasi pada anak bertujuan untuk memberikan kekebalan terhadap penyakit sehingga dapat menurunkan angka morbiditas dan mortalitas serta dapat mengurangi kecacatan akibat penyakit yang dapat dicegah dengan imunisasi (PD3I) seperti disentri, tetanus, batuk rejan (pertusis), campak (measles), polio dan tuberkulosis (Kemenkes RI, 2019; Oktiawati, Khodijah, Setyaningrum, \& Dewi, 2017).

Berdasarkan data Dinas Kesehatan Kabupaten Rejang Lebong tahun 2017 didapatkan jumlah cakupan imunsasi dasar lengkap di Kabupaten Bengkulu Utara sebanyak 4.013 orang dari 4.617 bayi. Dengan capaian tertinggi berada di Puskesmas Sumber Urib dan cakupan terendah berada di Puskesmas Sindang Beliti Ilir (Dinas Kesehatan Kabupaten Rejang Lebong, 2018).

Masih rendahnya cakupan kelengkapan imunisasi dapat disebabkan karena ada anggapan bahwa pemberian imunisasi tidak terlalu penting bagi bayinya karena dengan gizi yang baik mereka percaya bahwa bayinya akan tetap sehat, serta masih banyak ibu yang belum mengetahui tentang manfaat imunisasi, dampak bayi yang tidak mendapat imunisasi dan jadwal pemberian imunisasi. Ibu beranggapan setelah diimunisasi bayinya akan menjadi sakit, rewel dan bayinya menjadi bodoh karena telah disuntikan kuman-kuman. Bayi mendapatkan imunisasi atau tidak pada dasarnya tergantung dari pengetahuan ibu. Hal ini menunjukan bahwa pentingnya pengetahuan ibu tentang imunisasi mempunyai hubungan dengan tindakan ibu dalam pemberian imunisasi kepada bayinya. Ibu yang memiliki pengetahuan baik makaakan memahami manfaat dan pentingnya imunisasi sehingga akan mengusahakan kelengkapan imunisasi bagi bayinya (Proverawati \& Andhini, 2010).

Kelengkapan pemberian imunisasi pada anak dipengaruhi oleh berbagai faktor seperti usia anak, jumlah anak yangmasih hidup, tingkat pendidikan orang tua, kekayaan, sumber informasi kesehatan ibu dan anak, serta jumlah perawatan antenatal (Noh et al., 2018). Penelitian yang dilakukan oleh Konwea, 
David, \& Ogunsile (2018) menyatakan bahwa terdapat dua faktor yang berkontribusi signifikan terhadap kepatuhan ibu dalam pemberian imunisasi yaitu pengetahuan ibu tentang imunisasi anak dan status pendidikan ibu. Peneliti sebelumnya juga menyatakan faktor yang berhubungan dalam pencapaian imunisasi dasarlengkap yaitu tingkat pendidikan ibu, tingkat pengetahuan ibu, kepercayaan ibu dan sikapibu(Hudhah \& Hidajah, 2017).

Berdasarkan data Dinas Kesehatan Kabupaten Rejang Lebong tahun 2017 didapatkan jumlah cakupan imunsasi dasar lengkap di Kabupaten Bengkulu Utara sebanyak 4.013 orang dari 4.617 bayi. Dengan capaian tertinggi berada di Puskesmas Sumber Urib dan cakupan terendah berada di Puskesmas Sindang Beliti Ilir (Dinas Kesehatan Kabupaten Rejang Lebong, 2018).

\section{BAHAN DAN METODE}

Penelitian ini merupakan penelitian kuantitatif dengan desain survey analitik yang menggunakan rancangan penelitian cross sectional untuk mengidentifikasi hubungan antara hubungan antara pengetahuan ibu dengan kelengkapan imunisasi dasar.

Populasi dalam penelitian ini adalah seluruh ibu yang mempunyai bayi usia 9-12 bulan di wilayah kerja Puskesmas Sindang Belitir Ilir Kabupaten Rejang Lebong. Sampel dalam penelitian ini menggunakan teknik accidental sampling sebanyak 61 orang. Pengumpulan data dalam penelitian ini menggunakan data primer yang diperoleh dari wawancara dan penyebaran kuesioner pengetahuan kepada ibu yang mempunyai bayi usia 9-12 bulan di wilayah kerja Puskesmas Belitir Ilir Kabupaten Rejang Lebong. Data sekunder diperoleh dari rekam medis yang berisi tentang status kelengkapan imunisasi balita.

Analisis data menggunakan Uji Chi-Square untuk melihat hubungan antara pengetahuan ibu dengan kelengkapan imunisasi dasar.

\section{HASIL PENELITIAN}

Gambaran pengetahuan ibu tentang Imunisasi dasar bayi di Wilayah Kerja Puskesmas Sindang Belitir Ilir dapat dilihat pada tabel 1 .

Tabel 1. Gambaran pengetahuan ibu tentang Imunisasi dasar bayi di Wilayah Kerja Puskesmas Sindang Belitir Ilir

\begin{tabular}{cccc}
\hline No & Pengetahuan Ibu & Frekuensi & Persentase (\%) \\
\hline 1 & Kurang & 19 & 31,1 \\
2 & Cukup & 22 & 36,1 \\
3 & Baik & 20 & 32,8 \\
\hline & Jumlah & 61 & 100,0 \\
\hline
\end{tabular}

Tabel 1 menunjukkan hasil bahwa bahwa dari 61 ibu yang mempunyai bayi usia 9-12 bulanterdapat $19(31,2 \%)$ ibu dengan pengetahuan kurang, $22(36,1 \%)$ ibu dengan pengetahuan cukup dan 20
$(32,8 \%)$ orang ibu dengan pengetahuan baik.

Gambaran kelengkapan imunisasi dasar bayi di Wilayah Kerja Puskesmas Sindang Belitir Ilir dapat dilihat pada tabel 2 .

Tabel 2. Gambaran kelengkapan imunisasi dasar bayi di Wilayah Kerja PuskesmasSindangBelitir Ilir 


\begin{tabular}{cccc}
\hline No & $\begin{array}{c}\text { Kelengkapan Imunisasi } \\
\text { Dasar }\end{array}$ & Frekuensi & $\begin{array}{c}\text { Persentase } \\
(\mathbf{\% )})\end{array}$ \\
\hline 1 & Tidak lengkap & 22 & 36,1 \\
2 & Lengkap & 39 & 63,9 \\
\hline & Jumlah & 61 & 100,0 \\
\hline
\end{tabular}

Berdasarkan tabel 2diperoleh hasil bahwa dari 61 ibu yang mempunyai bayi usia 9-12 bulan sebagian besar terdapat $39(63,9 \%)$ orang responden memberikan imunisasi dasar lengkap pada bayinya dan terdapat $22(36,1 \%)$ orang responden tidak memberikan imunisasi dasar lengkap pada bayinya.

Hubungan antara hubungan pengetahuan ibu tentang imunisasi dasar dengan kelengkapan imunisasi dasar bayi di wilayah kerja Puskesmas Sindang Belitir Ilirdapat dilihat pada tabel 3.

Tabel 3 Hubungan pengetahuan ibu tentang imunisasi dasar dengan kelengkapan imunisasi dasar bayi di Wilayah Kerja Puskesmas Sindang Belitir Ilir

\begin{tabular}{|c|c|c|c|c|c|c|c|c|c|}
\hline \multirow{3}{*}{ Pengetahuan } & \multicolumn{4}{|c|}{ Kelengkapan Imunisasi } & \multirow{2}{*}{\multicolumn{2}{|c|}{ Total }} & \multirow{3}{*}{$\chi^{2}$} & \multirow{3}{*}{$\mathbf{P}$} & \multirow{3}{*}{$\mathbf{C}$} \\
\hline & \multicolumn{2}{|c|}{$\begin{array}{c}\text { Tidak } \\
\text { lengkap }\end{array}$} & \multicolumn{2}{|c|}{ Lengkap } & & & & & \\
\hline & $\mathbf{F}$ & $\%$ & $\mathbf{f}$ & $\%$ & $\mathbf{f}$ & $\%$ & & & \\
\hline Kurang & 13 & 68,4 & 6 & 31,6 & 19 & 100 & & & \\
\hline Cukup & 7 & 31,8 & 15 & 68,2 & 22 & 100 & 14,691 & 0,001 & 0,441 \\
\hline Baik & 2 & 10,0 & 18 & 90 & 20 & 100 & & & \\
\hline
\end{tabular}

Tabel 3 menunjukkan hasil tabulasi silang hubungan pengetahuan ibu tentang imunisasi dasar dengan kelengkapan imunisasi dasar bayi di wilayah kerja Puskesmas Sindang Belitir Ilirdiperoleh data dari $19 \mathrm{ibu}$ dengan pengetahuan kurang terdapat terdapat 13 orang tidak memberikan imunisasi dasar lengkap pada bayinya dan 6 orang memberikan imunisasi dasar lengkap pada bayinya. Dari 22 ibu dengan pengetahuan cukup terdapat 7 orang tidak memberikan imunisasi dasar lengkap pada bayinya dan 15 orang memberikan imunisasi dasar lengkap pada bayinya.Dari 20 orang ibu dengan pengetahuan baik terdapat 2 orang tidak memberikan imunisasi dasar lengkap pada balitanya dan 18 orang memberikan imunisasi dasar lengkap pada bayinya.

Hasil uji statistik Pearson ChiSquare diperoleh nilai $\chi^{2}=14,691$ dengan $\mathrm{p}=0,001<0,05$ jadi signifikan, sehingga Ho ditolak dan Ha diterima, artinya ada hubungan yang signifikan antara pengetahuan ibu tentang imunisasi dasar dengan kelengkapan imunisasi dasar bayi di Wilayah Kerja Puskesmas Sindang Belitir Ilir.

Hasil uji Contingency Coefficient didapat nilai $\mathrm{C}=0,441$ dengan $\mathrm{P}=0,001<0,05$ berarti signifikan. Nilai $\mathrm{C}$ tersebut dibandingkan dengan nilai $\mathrm{C}_{\max }=$ 0,707. Jadi nilai $\frac{C}{C_{\max }}=\frac{0,441}{0,707}=0,62$ karena nilai ini terletak dalam interval $0,6-0,8$ maka kategori hubungan erat.

\section{PEMBAHASAN}

Pengetahuan Ibu Tentang Imunisasi

Pengetahuan dan persepsi tentang vaksinasi merupakan hal penting yang 
diperlukan dalam membantu mengembangkan sikap positif terhadap vaksinasi dan kontribusi orang tua terhadap kelengkapan pemberian vaksinasi(Mugada, Chandrabhotla, Kaja, \& Machara, 2017).

Hasil penelitian ini menunjukkan bahwa dari 61 ibu yang mempunyai bayi usia 9-12 bulan terdapat $19(31,2 \%)$ ibu dengan pengetahuan kurang, $22(36,1 \%)$ ibu dengan pengetahuan cukup dan 20 $(32,8 \%)$ orang ibu dengan pengetahuan baik. Kondisi ini menunjukkanhampir sebagian ibu memiliki tingkat pengetahuan yang cukup tentang imunisasi, namun masih terdapat ibu yang memiliki pengetahuan kurang tentang imunisasi dasar. Hal ini disebabkan oleh kurangnya informasi tentang imunisasi dasar yang diterima oleh ibu.

Petugas puskesmas menyatakan sudah banyak media pemberian informasi tentang imunisasi dasar dapat diperoleh ibu baik itu melalui penyuluhan, media elekronik dan buku, namun mengingat kondisi masyarakat sebagian besar adalah petani, sehingga dapat dimungkinkan kurangnya informasi yang didapat karena ibu yang terlalu sibuk bekerja diladang dan kurangnya waktu untuk ikut dalam berbagai kegiatan yang dilakukan oleh pihak puskesmas.

Menurut Bernsen et al.,(2011), pengetahuan yang rendah tentang imunisasi terjadi pada orang tuayang tidak menerima informasi dari para profesional kesehatan. Untuk mempertahankan cakupan vaksinasi maka direkomendasikan kepada petugas kesehatan untuk berfokus untuk memberikan informasi terutama pada orang tua dengan menyesuaikan dan menargetkan informasi sesuai dengan tingkat pemahaman masing-masing orang tua.

\section{Kelengkapan Imunisasi Dasar Bayi}

Berdasarkan hasil penelitian, tampak bahwa dari 61 ibu yangmempunyai bayi usia $9-12$ bulan terdapat $22(36,1 \%)$ tidak memberikan imunisasi dasar lengkap pada bayinya dan terdapat $39 \quad(63,9 \%)$ memberikan imunisasi dasar lengkap pada bayinya. Hal ini menunjukan masih banyaknya masyarakat tidak memberikan bayinya imunisasi dasar hingga usia 9 bulan, namun ibu yang memberikan anaknya imunisasi dasar lengkap tepat waktu juga cukup banyak yaitu $63,9 \%$.Kondisi ini dipengaruhi oleh pengetahuan dan informasi yang didapatkan responden tentang imunisasi dasar. Selain pengetahuan yang baik, pendidikan dan status ekonomi juga mempengaruhi pemberian imunisasi dasar tepat waktu oleh ibu.

Namun hampir sebagian responden yaitu $36,1 \%$ tidak memberikan imunisasi dasar lengkap pada balita, hal ini dapat dilihat dari lembar jawaban isi kuesioner sebagian besar ibu balita menjawab tidak mengimunisasikan balitanya secara lengkap pada waktu usia 9-12 bulan yang terdiri dari imunisasi BCG, DPT-1, DPT-2, DPT-3, Polio-1, Polio-2, Polio-3, Polio-4, HB-1, HB-2, HB-3 dan Campak, dikarenakan oleh perbedaan pengetahuan yang dimiliki oleh masing-masing ibu balita. Sesuai dengan teori menurut Notoatmodjo (2014), faktor-faktor yang mempermudah atau mempredisposisi terjadinya perilaku seseorang antara lain pengetahuan, sikap, keyakinan, kepercayaan, nilai-nilai, tradisi dan sebagainya.

Menurut Proverawati (2015), imunisasi dasar adalah imunisasi pertama yang perlu diberikan pada semua orang, terutama bayi dan anak sejak lahir untuk melindungi tubuhnya dan penyakitpenyakit yang berbahaya. Lima jenis imunisasi dasar yang diwajibkan pemerintah adalah imunisasi terhadap tujuh penyakit, yaitu TBC, difteri, tetanus, pertusis (batuk rejan), poliomyelitis, campak dan hepatitis B. 
Hubungan pengetahuan dengan kelengkapan imunisasi dasar bayi

Berdasarkan tabulasi silang antarapengetahuan ibu dengan kelengkapan imunisasi dasar diatas menunjukkan dari 19 ibu dengan pengetahuan kurang terdapat 13 orang tidak memberikan imunisasi dasar lengkap pada bayinya. Kondisi ini menunjukkan bahwa pengetahuan memiliki pengaruh terhadap ketepatan ibu dalam memberikan imunisasi dasar pada anaknya, jika pengetahuan ibu kurang tentang imunisasi dasar maka ibu akan lalai dalam memberikan imunisasi yang tepat pada anaknya, karena ibu kurang mengetahui manfaat dari imunisasi dasar. Pengetahuan yang kurang pada ibu disebabkan oleh tingkat pendidikan ibu dan kurangnya informasi tentang imunisasi dasar yang ibu dapatkan, baik itu melalui penyuluhan imunisasi oleh petugas kesehatan, media cetak, media elektronik dan sebagainya

Dari 19 ibu dengan pengetahuan kurang terdapat 6 orang memberikan imunisasi dasar lengkap pada balitanya. Hal ini menunjukkan bahwa walaupun ibu memiliki pengetahuan yang kurang, jika didukung oleh motivasi dan sikap yang baik serta dukungan oleh suami, maka kelengkapan imunisasi dapat dicapai. Karena pada dasarnya tidak semua ibu mempunyai pendidikan yang baik dan memperoleh informasi yang cukup, namun jika didukung oleh suami dan keluarga maka kelengkapan imunisasi akan tercapai.

Dari 22 ibu dengan pengetahuan cukup terdapat 7 orang tidak memberikan imunisasi dasar lengkap pada bayinya dan 15 orang memberikan imunisasi dasar lengkap pada bayinya.Hal ini akan mempengaruhi ibu dalam memberikan imunisasi lengkap pada anaknya karena pengetahuan yang cukup menunjukkan ibu belum sepenuhnya pernah mendapatkan penyuluhan imunisasi, pengetahuan yang cukup jika tidak diiringi dengan dukungan suami atau keluarga yang baik juga akan menyebabkan ibu lalai dalam memberikan anaknya imunisasi dasar lengkap.

Dari 20 orang ibu dengan pengetahuan baik terdapat 2 orang tidak memberikan imunisasi dasar lengkap pada balitanya. Hal ini menunjukkan bahwa walaupun ibu dengan pengetahuan yang baik, imunisasi dasar tidak lengkap dapat terjadi. Karena kelengkapan imunisasi dasar dipengaruhi oleh banyak hal seperti faktor kesibukan. Hal ini dapat terjadi mengingat kondisi di Desa Sidang Beliti Ilir masyarakatnya mayoritas adalah petani dan kesehariannya sibuk diladang sehingga terkadang lupa jadwal imunisasi pada anaknya sehingga pemberian imunisasi dapat terlewat dari waktu dimana harus diberikan imunisasi, seperti dari 2 orang responden yang mengatakan bahwa mereka terlalu sibuk di ladang sehingga terlewat untuk melakukan imunisasi pada anaknya.

Dari 20 orang ibu dengan pengetahuan baik terdapat 18 orang memberikan imunisasi dasar lengkap pada bayinya. Pengetahuan yang baik pada ibu diperoleh dari tersedianya media informasi seperti media elektronik, media cetak dan penyuluhan yang diberikan oleh petugas kesehatan. Terlihat bahwa dengan pengetahuan yang baik maka kesadaran ibu untuk membawa anaknya untuk diimunisasi akan semakin meningkat. Kondisi menunjukkan bahwa pengetahuan yang baik akan mempengaruhi perilaku seseorang dalam memenuhi kebutuhan akan kesehatannya.

Hasil uji statistik Pearson ChiSquare diperoleh hubungan yang signifikan antara pengetahuan ibu tentang imunisasi dasar dengan kelengkapan imunisasi dasar bayi di Wilayah Kerja Puskesmas Sindang Belitir Ilir. 
Hasil ini sejalan dengan penelitian menurut Hijani (2013) yang melakukan penelitian tentang hubungan pengetahuan ibu tentang imunisasi terhadap kelengkapan imunisasi dasar pada balita di wilayah kerja Puskesmas Dumai Kota Kelurahan Dumai Kota, didapatkan hasil bahwa terdapat terdapat hubungan yang signifikan antara pengetahuan ibu tentang imunisasi terhadap kelengkapan imunisasi dasar pada balita di wilayah kerja Puskesmas Dumai Kota Kelurahan Dumai Kota

Penelitian lain menurut Atika (2013) yang melakukan penelitian tentang hubungan tingkat pengetahuan ibu dengan pemberian imunisasi dasar lengkap pada bayi di Kelurahan Parupuk Tabing Wilayah Kerja Puskesmas Lubuk Buaya Kota Padang Tahun 2013, didapatkan hasil bahwa terdapat hubungan yang signifikan antara tingkat pengetahuan ibu dengan pemberian imunisasi dasar lengkap pada bayi di Kelurahan Parupuk Tabing Wilayah Kerja Puskesmas Lubuk Buaya Kota Padang.

Sebagai upaya mencapai keberhasilan ketepatan pemberian imunisasi pada anak khususnya imunisasi dasar diperlukan pengetahuan orang tua yang baik tentang imunisasi dasar seingga program ini dapat tercapat sesuai dengan target yang diharapkan, maka diharapakan pada kader posyandu, petugas kesehatan dan tenaga penyuluh dipuskesmas untuk dapat memberikan informasi kepada masyarakat tentang imunisasi dengan melakukan promosi kesehatan, penyuluhan kesehatan, penyebaran leaflet, penyebaran poster dan membagikan buku tentang manfaat imunisasi kepada masyarakat.

Hasil uji Contingency Coefficient didapat kategori hubungan erat . Hasil ini menunjukkan bahwa pengetahuan seseorang Akan sangat mempengaruhi sikap cara pandang seseorang sehingga akan membentuk sikap yang diwujudkan dalam perilaku. Sejalan dengan Notoatmodjo (2014) melalui ilmu pengetahuan ibu akan lebih memiliki kesadaran dan mudah menerima sesuatu hal yang bermanfaat untuk perbaikan dalam dirinya. Semakin tinggi pengetahuan seseorang sehingga dapat menyebabkan mudah mendapatkan ideide dan teknologi khususnya pelayanan kesehatan, sebaliknya pengetahuan yang kurang akan menghambat perkembangan sikap seseorang terhadap perubahan hidup sehat.

Menurut penelitian Aziza (2014) yang melakukan penelitian tentang faktor-faktor yang berhubungan dengan kelengkapan imunisasi dasar pada bayi usia 9-11 bulan di Desa Sumberejo Kecamatan Mranggen Demak. Hasil penelitian menunjukkan ada hubungan yang bermakna antara pendidikan, pendapatan, pengetahuan dan sikap dengan kelengkapan imunisasi dasar pada bayi usia 9-11 bulan di Desa Sumberejo Kecamatan Mranggen Demak.

\section{KESIMPULAN}

Berdasarkan hasil penelitian hubungan pengetahuan ibu tentang imunisasi dasar dengan kelengkapan imunisasi dasar bayi di Wilayah Kerja Puskesmas Sindang Belitir Ilir, maka dapat disimpulkan bahwa ada hubungan yang signifikan antara pengetahuan ibu tentang imunisasi dasar dengan kelengkapan imunisasi dasar bayi di Wilayah Kerja Puskesmas Sindang Belitir Ilir, dengan kategori hubungan erat.

Hasil penelitian ini diharapkan dapat menjadi acuan bagi pihak puskesmas khusunya peraawat, bidan dan kader untuk dapat meningkatkan lagi pelayanan imunisasi dipuskesmas dan posyandu untuk meningkatkan minat ibu memberikan imunisasi dasar lengkap pada anaknya dan kepada perawat untuk dapat melakukan penyuluhan untuk memberikan informasi kepada ibu tentang pentingnya imunisasi pada anak agar 
dapat meningkatkan pengetahun ibu tentang imunisasi dasar khususnya. Selain itu hasil penelitian ini dapat menjadi sumber informasi bagi ibu tentang pentingyaimunisasi dasar bagi bayi sehingga diharapakan dapat menumbuhkan sikap yang mendukung pada ibu untuk memberikan imunisasi tepat waktu pada anaknya.

\section{DAFTAR PUSTAKA}

Atika, P. D. 2013. Hubungan Tingkat Pengetahuan Ibu Dengan Pemberian Imunisasi Dasar Lengkap Pada Bayi Di Kelurahan Parupuk Tabing Wilayah Kerja Puskesmas Lubuk Buaya Kota Padang Tahun 2013. Jurnal Kesehatan Andalas 3 (2) 114-118. http://jurnal.fk.unand.ac.id/index.ph $\mathrm{p} / \mathrm{jka} /$ article/view/43/38. Diakses pada tanggal 1 April 2019

Aziza, N. 2014.Faktor-Faktor Yang Berhubungan Dengan Kelengkapan Imunisasi Dasar Pada Bayi Usia 911 Bulan di Desa Sumberejo Kecamatan Mranggen Demak.Jurnal Kebidanan UMS 4 (1) 1724.https://jurnal.unimus.ac.id/index. php/jur bid/article/view/1385. Diakses pada tanggal 17 Juli 2019

Badan Pusat Statistik. (2018). Profil Kesehatan Ibu dan Anak 2018. Jakarta: Badan Pusat Statistik Indonesia.

Bernsen, R. M., Al-zahmi, F. R., Al-ali, N. A., Hamoudi, R. O., Ali, N. A., Schneider, J., \& Grivna, M. (2011). Knowledge , Attitude and Practice towards Immunizations among Mothers in a Traditional City in the United Arab Emirates, 4, 114-121.

Dinas Kesehatan Kabupaten Rejang Lebong. (2018). Laporan Imunisasi.

Dinas Kesehatan Provinsi Bengkulu. (2019). Profil Kesehatan Provinsi Bengkulu 2018.

Hijani 2013. Hubungan Pengetahuan Ibu Tentang Imunisasi Terhadap
Kelengkapan Imunisasi Dasar Pada Balita Di Wilayah Kerja Puskesmas Dumai Kota Kelurahan Dumai Kota. Jurnal Universitas Riau. https://media.neliti.com/media/publi cations/ 184880-ID.pdf. Diakses pada tanggal 1 April 2019.

Hudhah, M., \& Hidajah, A. C. (2017). Perilaku Ibu Dalam Imunisasi Dasar Lengkap Di Puskesmas Gayam Kabupaten Sumenep. Jurnal PROMKES, 5(2), 167. https://doi.org/10.20473/jpk.v5.i2.20 17.167-180

Kemenkes RI. (2019). Profil Kesehatan Indonesia 2018 [Indonesia Health Profile 2018]. Jakarta: Kementerian Kesehatan Republik Indonesia.

Konwea, P. E., David, F. A., \& Ogunsile, S. E. (2018). Determinants of compliance with child immunization among mothers of children under five years of age in Ekiti State, Nigeria. Journal of Health Research, 32(3), 229-236. https://doi.org/10.1108/jhr-05-2018024

Marmi, \& Rahardjo, K. (2012). Asuhan Neonatus, Bayi, Balita dan Anak Prasekolah. Yogyakarta: Pustaka Pelajar.

Mugada, V., Chandrabhotla, S., Kaja, D. S., \& Machara, S. G. K. (2017). Knowledge towards childhood immunization among mothers \& reasons for incomplete immunization. Journal of Applied Pharmaceutical Science, $\quad 7(10), \quad 157-161$. https://doi.org/10.7324/JAPS.2017.7 1023

Noh, J. W., Kim, Y. M., Akram, N., Yoo, K. B., Park, J., Cheon, J., ... Stekelenburg, J. (2018). Factors affecting complete and timely childhood immunization coverage in Sindh, Pakistan; A secondary analysis of crosssectional survey data. PLoS ONE, 13(10), 1-15. https://doi.org/10.1371/journal.pone. 
0206766

Notoatmodjo, S. 2014. Ilmu Perilaku

Kesehatan. Jakarta: Rineka Cipta

Oktiawati, A., Khodijah, Setyaningrum, I., \& Dewi, R. C. (2017). Teori dan Konsep Keperawatan Pediatrik. Jakarta: Trans Info Media.

Proverawati, A., \& Andhini, C. S. D. (2010). Imunisasi dan Vaksinasi. Jakarta: Nuha Medika. 